\title{
Effect of Body and Texture on Cultures, Sugar Levels and Storage Periods of Shrikhand
}

\author{
Shiv Sharan ${ }^{1 *}$, M. P. S. Yadav ${ }^{1}$, S. J. Singh ${ }^{1}$, S. K. Shahi ${ }^{2}$ and Devendra Singh ${ }^{1}$ \\ ${ }^{1}$ Animal Husbandry and Dairying, C. S. Azad University of Agriculture and Technology, \\ Knapur (U.P.), India \\ ${ }^{2}$ Animal Husbandry and Dairying, U.P. College (Autonomous) Bhojubir, \\ Varanasi (U.P.), India \\ *Corresponding author
}

A B S T R A C T

\section{Keyw ords \\ Body and texture, sugar, Culture, Storage periods, Flavor and Latococcous crimoris}

Article Info

Accepted:

20 January 2019

Available Online:

10 February 2020
An experiment was conducted to investigate the effect of body and texture on starter cultures, sugar levels and storage periods of Shrikhand at Department of Animal Husbandry and Dairying of Chandra Shekhar Azad University of Agriculture and Technology, Kanpur (U.P.) India. The results of the present investigation showed that the maximum score (8.00) was in case of fresh samples prepared from the combination of Lactococcus lactice subsp. cremoris with $40 \%$ sugar level and mango flvour (A2B2C2D1) followed by the combination of A2B2C2D1, A2B1C3D1, A3B1C3D1, A2B2C1D1 and A1B2C3D1, respectively which were statistically at par with respect to body and texture score of shrikhand and were graded excellent quality and liked extremely. The lowest score (3.00) was registered from A1B3C1D4 samples and were graded as poor quality.

\section{Introduction}

Shrikhand is a popular Indian dessert prepared by the fermentation of buffalo milk. It has semi-soft consistency and has a sweet and sour taste. Typically shrikhand constitutes 39.0 percent moisture and 61.0 percent of total solids of which 10.0 percent is fat, 11.5 percent proteins 78.0 percent carbohydrates and 0.5 percent ash, on a dry matter basis. It has a $\mathrm{pH}$ range of about 4.2 to 4.4 (Boghra and Mathur, 2000B). On an industrial scale shrikhand is prepared by using different mechanical devices (Aneja et al., 1977). In this process, pasteurized milk or skim milk is inoculated with the culture. Shrikhand prepared either from buffalo or cow's milk retained quantitatively all the constituents in proportion to the addition of sugar. Little or no change in $\mathrm{pH}$ was seen during the conversion of chakka into shrikhand. The mineral make-up remained more or less unchanged, except citrate which disappeared completely at dahi stage of both buffalo and 
cow's milk. The fermentation of milk brought about highly significant changes in mineral contents during transition from colloidal to soluble phase, which was faster and greater for buffalo milk (Boghra and Mathur, 2000A). India's market potential and current growth rate of traditional dairy products is unparalleled and all set to boom further under the technology of mass production. An estimated 50 to 55 percent of the milk produced in India is converted into a variety of traditional milk products, using processes such as coagulation, desiccation and fermentation. Indian fermented milk products utilize 7 percent of total milk produced and mainly includes three product dahi, shrikhand (sweetened concentrated curd) and lassi which may be considered the western equivalent to yogurt, quarg and stirred yogurt, respectively (Swapna and Chavannavar, 2011). Salunke and Patel (2006) concluded that there exists appreciable differences in the sensory quality of the product. The body and texture score of Shrikhand was highly affected by different sugar level (Singh et al., 2015). The best of sugar responded better as compared to low level so far as flavour of the product in concerned (Singh et al., 2015A).

\section{Materials and Methods}

The present investigation was carried out in the Department of Animal Husbandry and Dairying of C.S.A. University of Agriculture and Technology, Kanpur (U.P.) India.

The details of materials and methods used for preparation of Shrikhand.

\section{Milk}

Take fresh buffalo milk (6\% fat and 9\% SNF).

Starter culture (used during preparing of Shrikhand):
Streptococus lactics., Streptococus cremoris and Streptococus diacetilactis.

\section{Sugar}

Commercial grade white crystalline sugar free from impurities.

\section{Colour and flavour}

NO colours added and three type of flavours without colours, orange, mango and checked (No flavour).

\section{Packing materials}

Plastic cup was used for packaging.

\section{Methodology}

For preparing the Shrikhand buffalo milk was used and received from Department of Animal Husbandry and Dairying of Chandra Shekhar Azad University of Agriculture and Technology, Kanpur. Different cultures with flavoures and sugar were added for preparing Shrikhand (Flow Chart for Shrikhand Preparation is given as figure 1).

\section{Results and Discussion}

The body and texture score of Shrikhand is the most important quality attributes. A pleasant sweetish aroma and a mild clean acid taste are desirable characteristics of Shrikhand. It should be free from any off flavour. A good pleasant diacetyl flavour is desired in Shrikhand. It should not show any signs of bitterness, saltiness as any other off flavour. The body and texture score of Shrikhand as affected by different factors have been presented in Table 1 and its analysis of variance in Table 2 . These Table and figure 2 revealed the following facts. The results of present study as well as relevant discussion have been presented here: 
From Table No.-1 the means of different levels of all the factors, the following facts were observed. The highest (5.45) body and texture score was found in milk sample of $\mathrm{A}_{2}$ (Lactococcus cremoris) followed by $\mathrm{A}_{1}$ (Streptococus diacetilactis) score (5.153).

On comparing average scores of body and texture of Shrikhand in case of different types of sugar levels. It was observed that the best body and texture score (5.546) was noted in case of Shrikhand prepared with $40 \%$ sugar $\left(\mathrm{B}_{2}\right)$ and lowest score (5.081) in case of $45 \%$ sugar level $\left(\mathrm{B}_{3}\right)$. The present findings supports neck to neck with the findings of Chauhan and Abraham (2011) they observed that acidity, $\mathrm{pH}$, firmness and stickiness increases with increase in insulin level whereas whey separation, flavour, body texture and overall acceptability and microbiological analysis decreased with increase in insulin level.

Effect of flavouring agent (C) on body and texture score of Shrikhand, it was observed that the highest score (5.451) was obtained from mango flavour $\left(\mathrm{C}_{3}\right)$ followed by orange flavour $\left(\mathrm{C}_{2}\right)$. The lowest body and texture score (5.093) was observed from Shrikhand prepared by without flavouring agent. $\left(\mathrm{C}_{1}\right)$.

As regard the storage periods, the maximum body and texture score (7.402) of Shrikhand was recorded in fresh samples while, minimum (3.446) was found when samples stored at 21 days.

From Table No.-1 denoting the mean interactions between type starter cultures (A) and Sugar levels (B), it was recorded that Shrikhand prepared from Lactococcus lactice subsp. cremoris with $40 \%$ sugar $\left(\mathrm{A}_{2} \mathrm{~B}_{2}\right)$ showed maximum score (5.650), while minimum body and texture score (4.933) was observed from $\left(\mathrm{A}_{1} \mathrm{~B}_{3}\right)$ samples.
Among the blend treatment combinations of type of starter cultures (A) and flavouring agents (C), the maximum body and texture score (5.656) was observed from Lactococcus lactice subsp. cremoris with mango flavour $\left(\mathrm{A}_{2} \mathrm{C}_{3}\right)$, whereas minimum body and texture score (4.933) registered from $\left(\mathrm{A}_{1} \mathrm{C}_{1}\right)$.

From the interaction A.D, it was observed that highest body and texture score (7.60) was in fresh samples of Lactococcus cremoris subsp. cremoris $\left(\mathrm{A}_{2} \mathrm{D}_{1}\right)$. The next maximum body and lactice texture score (7.40) was in case of $\left(\mathrm{A}_{3} \mathrm{D}_{1}\right)$. While minimum body and texture score (3.30) was noted in $\left(\mathrm{A}_{1} \mathrm{D}_{4}\right)$ samples.

Among the treatment combination of sugar levels and flavouring agents (B.C), it was observed that maximum body and texture score (5.658) in case of sample prepared with $40 \%$ sugar level and mango flavour $\left(\mathrm{B}_{2} \mathrm{C}_{3}\right)$ followed by $\left(\mathrm{B}_{1} \mathrm{C} 2\right)$ and $\left(\mathrm{B}_{3} \mathrm{C}_{3}\right)$ and minimum score (5.056) was obtained from $45 \%$ sugar level without flavouring agent $\left(\mathrm{B}_{3} \mathrm{C}_{2}\right)$.

From the mean interactions of B.D, it was found observed that the highest body and texture score (7.67) noted in fresh samples of $40 \%$ sugar levels $\left(\mathrm{B}_{2} \mathrm{D}_{1}\right)$ followed by $\mathrm{B}_{1} \mathrm{D}_{1}$, while minimum body and texture score (3.319) was obtained from $\left(\mathrm{B}_{3} \mathrm{D}_{4}\right)$ samples.

From interactions C.D, it was investigated that maximum body and texture score (7.60) of Shrikhand was in case of fresh sample prepared with mango flavour $\left(\mathrm{C}_{3} \mathrm{D}_{1}\right)$ followed by $\mathrm{C}_{2} \mathrm{D}_{1}$ score of (7.40) and minimum score (3.333) was recorded in $\mathrm{C}_{1} \mathrm{D}_{4}$. samples.

From Table No.-1 the effect of types of starter cultures, sugar levels, flavouring agents and storage periods (ABCD) on body and texture score of Shrikhand. 
Table.1 Effect of body and texture on cultures, sugar levels and storage periods of Shrikhand

\begin{tabular}{|l|l|l|l|l|l|l|l|l|l|l|l|}
\hline Treatments & B1 & B2 & B3 & C1 & C2 & C3 & D1 & D2 & D3 & D4 & Mean \\
\hline A1 & 5.033 & 5.253 & 4.933 & 4.933 & 5.044 & 5.242 & 7.207 & 5.785 & 4.00 & 3.300 & 5.073 \\
\hline A2 & 5.467 & 5.650 & 5.261 & 5.267 & 5.456 & 5.656 & 7.600 & 6.207 & 4.422 & 3.607 & 5.459 \\
\hline A3 & 5.273 & 5.483 & 5.050 & 5.078 & 5.272 & 5.456 & 7.400 & 6.044 & 4.200 & 3.430 & 5.269 \\
\hline B1 & & & & 5.078 & 5.256 & 5.439 & 7.400 & 6.015 & 4.222 & 3.393 & 5.257 \\
\hline B2 & & & & 5.267 & 5.461 & 5.658 & 7.607 & 6.215 & 4.400 & 3.626 & 5.462 \\
\hline B3 & & & & 4.933 & 5.056 & 5.256 & 7.200 & 5.807 & 4.00 & 3.319 & 5.081 \\
\hline C1 & & & & & & & 7.207 & 5.807 & 4.022 & 3.333 & 5.093 \\
\hline C2 & & & & & & & 7.400 & 6.015 & 4.200 & 3.415 & 5.257 \\
\hline C3 & & & & & & & 7.600 & 6.215 & 4.400 & 3.589 & 5.451 \\
\hline Mean & 5.250 & 5.462 & 5.081 & 5.092 & 5.257 & 5.451 & 7.402 & 6.012 & 4.207 & 3.446 & 5.266 \\
\hline
\end{tabular}

Table.2 Analysis of variance for body\& texture of Shrikhand

\begin{tabular}{|l|l|l|l|l|}
\hline S.V & Df & S.S & MSS & F. Ratio \\
\hline A & 2 & 8.053 & 4.026 & $136.339 * * *$ \\
\hline $\mathbf{B}$ & 2 & 7.837 & 3.918 & $132.685 * * *$ \\
\hline $\mathbf{C}$ & 2 & 6.949 & 3.475 & $117.656 * * *$ \\
\hline $\mathbf{D}$ & 3 & 774.014 & 258.005 & $8736.448 * * *$ \\
\hline AxB & 4 & 0.191 & 0.048 & $1.620 *$ \\
\hline AxC & 4 & 0.099 & 0.025 & 0.835 N.S \\
\hline AxD & 6 & 0.173 & 0.029 & 0.976 N.S \\
\hline BxC & 4 & 0.063 & 0.016 & 0.537 N.S \\
\hline BxD & 6 & 0.205 & 0.034 & $1.157 *$ \\
\hline CxD & 6 & 0.222 & 0.037 & $1.251 *$ \\
\hline AxBxC & 8 & 0.627 & 0.078 & $2.654 *$ \\
\hline AxBxD & 12 & 0.971 & 0.081 & $2.739 *$ \\
\hline AxCxD & 12 & 0.875 & 0.073 & $2.469 *$ \\
\hline BxCxD & 12 & 0.785 & 0.065 & $2.216 *$ \\
\hline AxBxCxD & 24 & 3.058 & 0.127 & $4.314 *$ \\
\hline Error & 216 & 6.379 & 0.030 & \\
\hline Total & 323 & 810.614 & 2.510 & \\
\hline & & & & \\
\hline
\end{tabular}


Fig.1 Flow Chart for Shrikhand Preparation

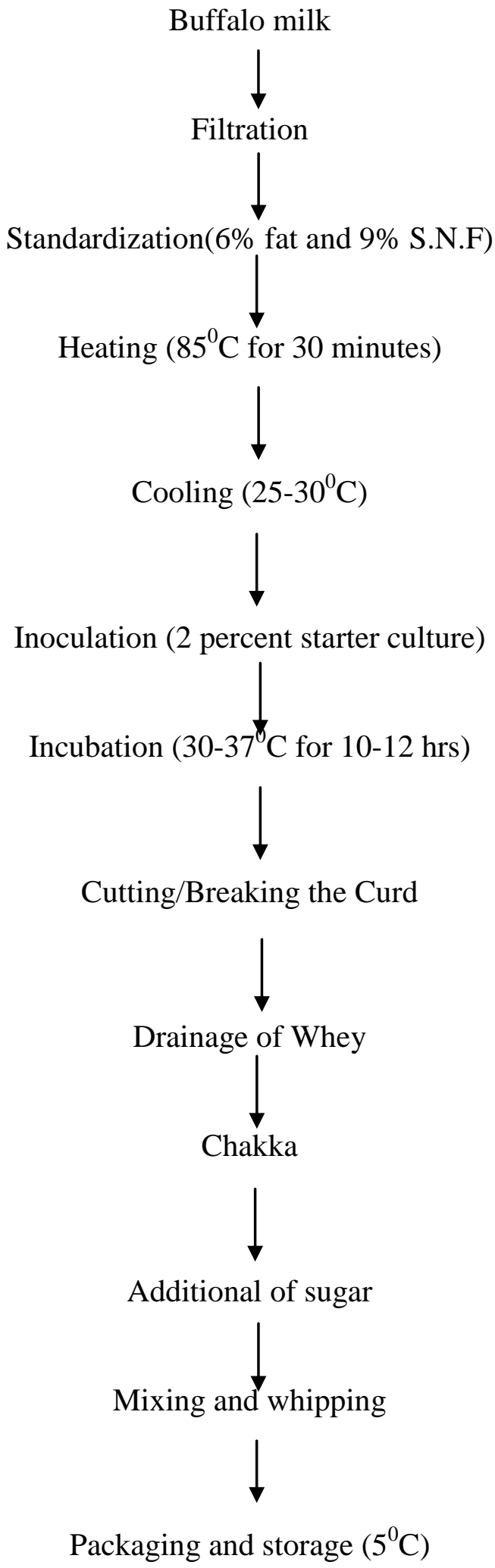


Fig.2 Effect of body and texture on cultures, sugar levels and storage periods of Shrikhand

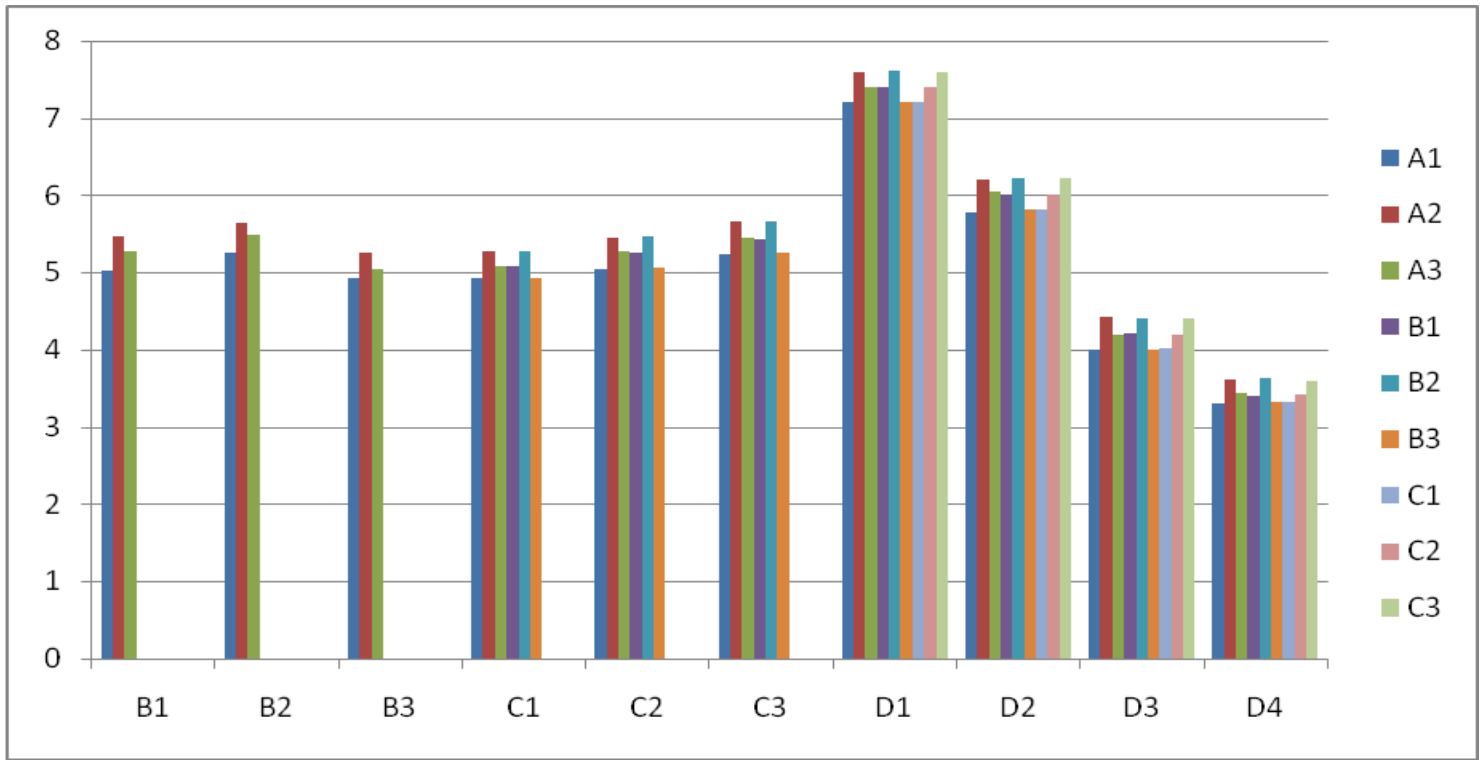

It was investigated that maximum score (8.00) was in case of fresh samples prepared from the combination of Lactococcus lactice subsp. cremoris with $40 \%$ sugar level and mango flvour $\left(\mathrm{A}_{2} \mathrm{~B}_{2} \mathrm{C}_{2} \mathrm{D}_{1}\right)$ followed by the combination of $\quad \mathrm{A}_{2} \mathrm{~B}_{2} \mathrm{C}_{2} \mathrm{D}_{1}, \quad \mathrm{~A}_{2} \mathrm{~B}_{1} \mathrm{C}_{3} \mathrm{D}_{1}$, $\mathrm{A}_{3} \mathrm{~B}_{1} \mathrm{C}_{3} \mathrm{D}_{1}, \quad \mathrm{~A}_{2} \mathrm{~B}_{2} \mathrm{C}_{1} \mathrm{D}_{1}$ and $\mathrm{A}_{1} \mathrm{~B}_{2} \mathrm{C}_{3} \mathrm{D}_{1}$, respectively which were statistically at par with respect to body and texture score of Shrikhand and were graded excellent quality and liked extremely. The lowest score (3.00) was registered from $\mathrm{A}_{1} \mathrm{~B}_{3} \mathrm{C}_{1} \mathrm{D}_{4}$ samples and were graded as poor quality.

The analysis of variance Table No.-2 for body and texture score of Shrikhand, it was revealed that the main effect of factors A, B, $\mathrm{C}$ and $\mathrm{D}$ was found to be highly significant and the rest all first, second order interactions were observed to be non- significant and third order interactions is significant.

In conclusion on the basis of the present investigation it has been found that the Lactococcous crimoris culture with $40 \%$ sugar level and mango flavor had best compatibility with body and texture of Shrikhand.

\section{Acknowledgement}

The author thanks the Head, Department of Animal Husbandry and Dairying, to provide essential material and equipment for conducting an experiment in Laboratory, Department of A. H. and Dairying of Chandra Shekhar Azad University of Agriculture and Technology Kanpur -208002 (U.P.) and for the necessary facilities that were made available to carry out the research work.

\section{References}

Aneja, V., Nanda, and Thareja (1977). Development of an industrial process for the manufacture of Shrikhand. Journal of Food Science Technology; 14:159-163.

Boghra and Mathur, O.N. (2000). Physicochemical status of major milk constituents and minerals at various stages of shrikhand preparation. Journal of food science and Technology (Mysore); 37(2): 111-115.

Chauhan, R. and Abraham, J. (2011). A comparative study of different insulin levels on quality parameters of 
symbiotic mistidahi. Journal of Pune and Applied Microbiology; 5(2):977982.

Prafulla Salunke; Patel, H. A.; Thakar, P. N. (2006). Sensory profile of market shrikhand sold in Maharashtra State. Indian Journal of Dairy Science; 59(6): 363-368.

Sharma, U.P. and Zariwala, L.T. (1980). Deterioration of Shrikhand during storage. Journal of Dairy Science; 33(2): 223-231.
Singh, M.; Gupta, R.; Andhare, B. C. and Singh, S. (2015). Effect of fat and sugar on sensory quality of Shrikhand. Research Journal of Animal Husbandry and Dairy Science; 6(1): $52-56$

Swapna, G. Brahmaprakash, G.P. and Chavannavar, S.V. (2011). Development of functional food: Shrikhand. Environment and Ecology; 29(3A): 1326-1332.

\section{How to cite this article:}

Shiv Sharan, M. P. S. Yadav, S. J. Singh, S. K. Shahi and Devendra Singh. 2020. Effect of Body and Texture on Cultures, Sugar Levels and Storage Periods of Shrikhand. Int.J.Curr.Microbiol.App.Sci. 9(02): 2349-2355. doi: https://doi.org/10.20546/ijcmas.2020.902.267 